\title{
Leaf Water Potential of the Purple Elephant Grass, Pennisetum purpureum Schumach. (poaceae) and it's Relationship with Soil Moisture
}

\author{
Euriel Millán-Romero" ${ }^{*}$, Andrés Mass-Cruz², Yerye Chajin-Salcedo² and Carlos Millán-Páramo \\ ${ }^{1}$ Faculty of Engineering, University of Sucre, Cra. 28 \# 5-267, Sincelejo, Colombia; euriel.millan@unisucre.edu.co, \\ carlos.millan@unisucre.edu.co \\ 2University of Sucre, Cra. 28 \# 5-267, Sincelejo, Colombia; anelma95@gmail.com, yerye06@gmail.com
}

\begin{abstract}
Objectives: To investigate how the time of day affects the water potential values of the purple elephant grass (Pennisetum purpureum) in areas with and without irrigation during the dry season and the relation with soil moisture, in order to establish a good performance of the crop. Method: Water potential was measured with the Scholander pressure chamber and humidity was measured with a Moisture Soil Kit. Four demonstration plots of $3 \mathrm{~m} \times 3 \mathrm{~m}$ (three with irrigation and one without irrigation) were select and the determination was made at: 08:00, 13:00 and 17:00, for 10 weeks two days a week. Findings: The crop under irrigation maintained values of water potential between 0.02 to $0.05 \mathrm{MPa}$, and crop without irrigation between 0.02 and $0.25 \mathrm{MPa}$. Additionally, a higher yield was obtained for the irrigated crop of $22 \mathrm{t} / \mathrm{ha}$ /year in dry matter. The purple elephant grass maintains a good yield with humidity between $20 \%$ and $30 \%$ and water potential between 0.03 and $0.05 \mathrm{MPa}$. Novelty /Improvement: Obtaining the equation $\left(\mathrm{Y}=0.493 * \mathrm{X}^{-0.775}\right)$ that relates soil moisture and leaf water potential of purple elephant grass Pennisetum purpureum Schumach. (Poaceae), which can be used to find the water potential $(\mathrm{Y})$ in a soil with a sandy clay loam texture.
\end{abstract}

Keywords: Availability of Water in the Plant, Pennisetum purpureum, Performance, Soil Moisture, Time, Water Potential

\section{Introduction}

In recent years, Colombia and especially the department of Sucre have been immersed in a great economic loss due to climate change, generating food shortages and death of animals 1 . For this reason, the implementation of irrigated pasture becomes important to supply and optimize the demand for water in the dry season, likewise take advantage of high rainfall in rainy weather for storage (silage). This makes it necessary to know the water potential in the plant for optimize the water resource.

Growth and development of plants is influenced by the environment, especially for the availability of water, since it intervenes in virtually all physiological processes ${ }^{2}$. The water deficit is due to the drought that triggers metabolic and physiological responses in plants affecting respiration, photosynthesis, anatomical and metabolic reactions, absorption of nutrients, development, growth, production, among others ${ }^{3}$. The knowledge of the various ecophysiological strategies in the use of water by the species of the different communities is key to be able to predict their response to fluctuations in the hydrological cycle susceptible to change by human activities, to establish sustainable forest and livestock programs ${ }^{4}$.

In plants, water typically constitutes $80 \%$ to $95 \%$ of the mass of the growing tissues, where it performs essential functions. For this reason, the measurement of the water potential with the Scholander pressure chamber, which is an equipment that can be used successfully to evaluate water stress in several plant species ${ }^{5}$,

${ }^{*}$ Author for correspondence 
has become very helpful for farmers who have chosen to introduce crops into their farms of pastures under irrigation, which are provided to the animals in the dry season ${ }^{6}$.

Several researchers have been studied the water potential of many plants and relate it with humidity present in the soil in order to make an adequate irrigation planning which allows the rational use of water. For example, Miras et al.. assessed the usefulness of the capacitance technique as a measurement of the soil water content and its relationship with leaf water potential in order to monitor vineyard irrigation; Garcia, Gonzalez and Montero ${ }^{8}$ evaluated the effect of the day time on measurement of leaf water potential in sorghum and its relationship with the soil volumetric humidity, during the cultivation of sorghum plants, showing that it is possible to use the leaf water potential as another alternative for the programming of irrigation in agricultural crops; Garzon, Velez and Orduz ${ }^{9}$ evaluated the effect of water deficit by controlled application of water through soil profile in orange crop Valencia (Citrus sinensis Osbeck) in the foothills Meta department, Colombia, showing that this variety (Valencia) has a fast recovery under suitable water supply conditions; May-Lara et al. $\stackrel{10}{ }$ evaluated the effect of soil moisture levels in the growth of Capsicum chinence Jacq plants and survival and development of Bemisia tabaci Genn, a direct positive correlation was found between the soil moisture and the plant water potential.

The aim of this study was to evaluate the incidence of time of day in the leaf water potential of the purple elephant grass with and without irrigation in dry season and the relationship with soil moisture, to establish the behavior of the crop.

\section{Materials and Methods}

The study was done in 2016 in the farm "El Achiote" in the town San Jorge located at $7 \mathrm{~km}$ from Sincelejo (Department of Sucre, Colombia) at $09^{\circ} 21^{\prime} 38,4^{\prime \prime} \mathrm{N}$ and $75^{\circ} 24^{\prime} 02,6^{\prime \prime} \mathrm{W}$, altitude of 200 meters above sea level, climate of tropical dry forest with average temperature of $28^{\circ} \mathrm{C}$ and relative humidity of $72 \%$.

\subsection{Determination of Moisture and Water Potential}

Soil moisture kit was utilized to obtain the volumetric humidity $(\theta)$. This equipment was installed near the stem of the plant to measure the water potential. Gravimetric humidity $\left(H_{g}\right)$ is calculated with the following equation, considering the apparent density of the soil $(D a)$ :

$$
H_{g}=\frac{\theta}{D a}
$$

The physical and chemical properties of the soil (Table 1) were determinate in the Laboratory of Water and Soil (LASA) of the University of Sucre (Colombia) following the methodology established in the analytical methods of the soil laboratory of the IGAC (Geographical Institute 'Agustin Codazzi') ${ }^{\underline{11}}$.

Table 1. Physical and chemical properties

\begin{tabular}{|l|l|l|}
\hline Determination & Method or equation & Value \\
\hline Texture & Bouyoucos & Sandy clay loam \\
\hline Apparent density & Clod of paraffined soil & $1.23 \mathrm{~g} / \mathrm{cm} 3$ \\
\hline $\mathrm{pH}$ & Potentiometric 1:1 NTC 5264 & 6.72 \\
\hline Organic matter \% & Organic carbon (Walkley. A., Black I.A.) & 2.12 \\
\hline & $\% H=\frac{\left(W_{h}+W r\right)-(W s+W r)}{(W s+W r)-W r} * 100$ & 29.17 \\
\hline Soil moisture \% & & \\
\hline Phosphorus $(\mathrm{ppm})$ & Bray II & 8.20 \\
\hline C.I.C. $(\mathrm{meq} / 100 \mathrm{gr}$ soil $)$ & Ammonium acetate $1 \mathrm{~N} \mathrm{Y} \mathrm{N}$ & 26.00 \\
\hline Calcium $(\mathrm{Cmol} / \mathrm{kg}$ soil) & Complexometric & 24.00 \\
\hline Magnesium $(\mathrm{Cmol} / \mathrm{kg}$ soil $)$ & Complexometric & 10.27 \\
\hline Potassium $(\mathrm{Cmol} / \mathrm{kg}$ soil $)$ & A.A & 0.21 \\
\hline Sodium $(\mathrm{Cmol} / \mathrm{kg}$ soil $)$ & A.A & 2.20 \\
\hline
\end{tabular}




\begin{tabular}{|l|l|l|}
\hline Determination & Method or equation & Value \\
\hline Aluminum (Cmol/kg soil) & Complexometric & - \\
\hline Calcium saturation (\%) & & 65.43 \\
\hline Magnesium saturation (\%) & & 28.00 \\
\hline Sodium saturation (\%) & - & 6.00 \\
\hline Aluminum saturation (\%) & - & - \\
\hline Relation calcium/magnesium (\%) & - & 2.34 \\
\hline Electric conductivity (MicroS/cm) & Saturated paste & 664 \\
\hline Salinity & Saturated paste & 0.3 \\
\hline
\end{tabular}

The water potential was obtained with a Scholander pressure chamber. Four demonstration plots of $3 \mathrm{~m} \times 3 \mathrm{~m}$ (three with irrigation and one without irrigation) were select and the determination was made at: 08:00, 13:00 and 17:00, for 10 weeks two days a week, starting on February 26 and ending on May 5, 2016.

The purple elephant grass Pennisetum purpureum Schumach. (Poaceae) was irrigated with a sprinkler irrigation system. Three sprinklers (SENNINGER model 3023) with wet radius of $12.5 \mathrm{~m}$ were select. The uniformity coefficient was evaluated, taking as reference ISO 11545 and ISO 7749-2 standards additionally, several containers were placed at $1 / 3$ and $2 / 3$ of the wetting radius in 4 directions. The system was put into operation for one hour; then the volume captured in each container was measured.

The results were analyzed by coefficient of variation, coefficient of correlation and linear regression. The Tukey's test was employed to find means that are significantly different from each other, using Statgraphics Centurion software. It was established a factorial of $2 \times 3$, that is, two variables (hydric potential and humidity) and three daily measurements, trough randomized complete blocks designs with three replications.

\section{Results and Discussion}

Table 2 shows the uniformity of the irrigation system. As observed, the irrigation system presents a uniformity within the accepted range, therefore the same irrigation time was used for all the areas. Additionally, the flow rates in each sprinkler have close values ensuring proper functioning in the system. The value of Distribution Uniformity (DU) is calculated as:

$$
\begin{aligned}
Q_{\text {avg }} & =\frac{36,815+31,416+38,615}{3} \\
Q_{\text {avg }} & =3,5015 \mathrm{~m}^{3} / \mathrm{h} \\
D U & =\frac{Q_{\text {min }}}{Q_{\text {avg }}} * 100 \\
D U & =\frac{31,416}{35,015} * 100 \\
D U & =89.72 \%
\end{aligned}
$$

There is no universal value of DU for satisfactory system performance but generally a value $>80 \%$ is considered acceptable $\underline{12}$.

Table 2. Calculation of irrigation uniformity

\begin{tabular}{|c|l|l|l|l|l|l|}
\hline & \multicolumn{2}{l|}{ Sprinkler 1 } & \multicolumn{2}{l|}{ Sprinkler 2 } & \multicolumn{2}{l|}{ Sprinkler 3 } \\
\hline & \multicolumn{2}{|l}{ Container } & \multicolumn{2}{l|}{ Container } & \multicolumn{2}{l|}{ Container } \\
\hline \multirow{3}{*}{ Line } & $\mathbf{1}$ & $\mathbf{2}$ & $\mathbf{1}$ & $\mathbf{2}$ & $\mathbf{1}$ & $\mathbf{2}$ \\
\hline \multirow{3}{*}{$\mathbf{1}$} & 3.7 & 5.3 & 4.3 & 4,7 & 7,3 & 10,7 \\
\cline { 2 - 7 } & 5.3 & 5.0 & 4.7 & 5,3 & 7,3 & 7,3 \\
\cline { 2 - 7 } & 5.3 & 5.0 & 4.7 & 5,3 & 7,3 & 7,3 \\
\hline \multirow{3}{*}{$\mathbf{2}$} & 9.0 & 6.3 & 7.3 & 8,7 & 9,3 & 3,7 \\
\cline { 2 - 7 } & 12.0 & 10.7 & 6.0 & 8,7 & 9,3 & 6,7 \\
\cline { 2 - 7 } & 12.0 & 10.7 & 6.0 & 8,7 & 9,3 & 6,7 \\
\hline
\end{tabular}


Leaf Water Potential of the Purple Elephant Grass, Pennisetum purpureum Schumach. (poaceae) and it's Relationship with Soil

\begin{tabular}{|c|c|c|c|c|c|c|}
\hline & \multicolumn{2}{|l|}{ Sprinkler 1} & \multicolumn{2}{|c|}{ Sprinkler 2} & \multicolumn{2}{|l|}{ Sprinkler 3} \\
\hline & \multicolumn{2}{|l|}{ Container } & \multicolumn{2}{|l|}{ Container } & \multicolumn{2}{|l|}{ Container } \\
\hline Line & 1 & 2 & 1 & 2 & 1 & 2 \\
\hline \multirow{3}{*}{3} & 10.0 & 10.7 & 9.3 & 4,3 & 12,7 & 4,0 \\
\hline & 8.0 & 10.0 & 9.0 & 6,0 & 7,3 & 7,3 \\
\hline & 7.3 & 10.7 & 9.7 & 5,3 & 6,0 & 6,0 \\
\hline \multirow{3}{*}{4} & 5.0 & 5.3 & 5.0 & 6,0 & 7,3 & 6,7 \\
\hline & 5.3 & 5.3 & 5.0 & 6,7 & 4,7 & 10,0 \\
\hline & 5.3 & 5.3 & 5.3 & 5,3 & 5,3 & 9,0 \\
\hline Average $(\mathrm{mm} / \mathrm{h})$ & 7.4 & 7.5 & 6.4 & 6,3 & 7,8 & 7,1 \\
\hline Average $(\mathrm{mm} / \mathrm{h})$ & \multicolumn{2}{|c|}{7.5} & \multicolumn{2}{|c|}{6.4} & \multicolumn{2}{|c|}{7.5} \\
\hline Flow $\left.\left(\mathbf{m}^{3} / \mathbf{h}\right)\right)$ & \multicolumn{2}{|c|}{3.6815} & \multicolumn{2}{|c|}{3.1416} & \multicolumn{2}{|c|}{3.6815} \\
\hline Area $\left(\mathbf{m}^{2}\right)$ & \multicolumn{2}{|c|}{490.875} & \multicolumn{2}{|c|}{490.875} & \multicolumn{2}{|c|}{490.875} \\
\hline
\end{tabular}

Table 3. Water potential (P) and humidity () at 08:00, 13:00 and 17:00, during the 20 days of testing

\begin{tabular}{|c|c|c|c|c|c|c|c|c|c|c|c|}
\hline \multicolumn{4}{|c|}{ Hour 08:00 } & \multicolumn{4}{|c|}{ Hour 13:00 } & \multicolumn{4}{|c|}{ Hour 17:00 } \\
\hline \multicolumn{2}{|c|}{ With irrigation } & \multicolumn{2}{|c|}{ Without irrigation } & \multicolumn{2}{|c|}{ With irrigation } & \multicolumn{2}{|c|}{ Without irrigation } & \multicolumn{2}{|c|}{ With irrigation } & \multicolumn{2}{|c|}{ Without irrigation } \\
\hline $\mathbf{P}(\mathrm{MPa})$ & $\mathbf{H}_{\mathrm{g}}(\%)$ & $\mathbf{P}(\mathrm{MPa})$ & $\mathrm{H}_{\mathrm{g}}(\%)$ & $\mathbf{P}(\mathrm{MPa})$ & $H_{g}(\%)$ & $\mathrm{P}(\mathrm{MPa})$ & $\mathbf{H}_{\mathrm{g}}(\%)$ & $\mathrm{P}(\mathrm{MPa})$ & $\mathrm{H}_{\mathrm{g}}(\%)$ & $\mathbf{P}(\mathrm{MPa})$ & $\mathrm{H}_{\mathrm{g}}(\%)$ \\
\hline 0.05 & 8.5 & 0.08 & 1.79 & 0.07 & 6.41 & 0.25 & 1.92 & 0.09 & 9.70 & 0.10 & 2.79 \\
\hline 0.04 & 12.9 & 0.12 & 3.71 & 0.10 & 10.23 & 0.21 & 1.68 & 0.10 & 8.48 & 0.24 & 2.74 \\
\hline 0.07 & 9.46 & 0.21 & 2.20 & 0.08 & 8.78 & 0.16 & 3.36 & 0.09 & 13.15 & 0.09 & 4.07 \\
\hline 0.06 & 9.96 & 0.15 & 3.69 & 0.07 & 6.65 & 0.12 & 2.47 & 0.10 & 6.86 & 0.12 & 1.76 \\
\hline 0.05 & 6.24 & 0.14 & 3.63 & 0.09 & 6.08 & 0.16 & 2.22 & 0.07 & 6.97 & 0.12 & 2.95 \\
\hline 0.09 & 10.57 & 0.16 & 3.17 & 0.08 & 12.29 & 0.19 & 4.01 & 0.11 & 7.28 & 0.12 & 4.82 \\
\hline 0.09 & 9.71 & 0.13 & 4.77 & 0.08 & 9.87 & 0.10 & 4.20 & 0.08 & 15.08 & 0.17 & 4.91 \\
\hline 0.05 & 14.83 & 0.15 & 5.12 & 0.07 & 10.54 & 0.19 & 3.58 & 0.09 & 13.58 & 0.14 & 5.96 \\
\hline 0.08 & 14.86 & 0.08 & 5.61 & 0.06 & 14.99 & 0.29 & 5.01 & 0.09 & 17.70 & 0.20 & 4.01 \\
\hline 0.06 & 16.07 & 0.17 & 3.69 & 0.07 & 18.15 & 0.22 & 6.42 & 0.10 & 13.67 & 0.25 & 5.56 \\
\hline 0.07 & 13.47 & 0.15 & 5.77 & 0.06 & 15.79 & 0.15 & 2.36 & 0.08 & 14.00 & 0.23 & 1.52 \\
\hline 0.07 & 20.41 & 0.18 & 9.84 & 0.07 & 21.32 & 0.23 & 11.38 & 0.09 & 15.75 & 0.18 & 7.53 \\
\hline 0.05 & 19.14 & 0.12 & 7.21 & 0.14 & 14.03 & 0.29 & 5.99 & 0.11 & 13.65 & 0.17 & 2.41 \\
\hline 0.06 & 22.35 & 0.14 & 19.30 & 0.10 & 18.85 & 0.10 & 18.48 & 0.06 & 22.99 & 0.14 & 17.15 \\
\hline 0.06 & 21.64 & 0.18 & 6.64 & 0.08 & 19.75 & 0.17 & 10.54 & 0.07 & 21.86 & 0.19 & 11.00 \\
\hline 0.06 & 24.85 & 0.14 & 22.22 & 0.07 & 23.08 & 0.13 & 17.89 & 0.05 & 22.57 & 0.09 & 15.39 \\
\hline 0.03 & 19.94 & 0.05 & 20.30 & 0.04 & 19.38 & 0.04 & 18.10 & 0.03 & 27.51 & 0.09 & 22.44 \\
\hline 0.02 & 26.46 & 0.02 & 21.27 & 0.03 & 22.73 & 0.03 & 22.38 & 0.03 & 23.43 & 0.02 & 27.94 \\
\hline 0.05 & 28.80 & 0.09 & 29.02 & 0.05 & 26.52 & 0.09 & 25.93 & 0.05 & 28.18 & 0.06 & 22.44 \\
\hline 0.02 & 25.97 & 0.02 & 18.40 & 0.03 & 25.84 & 0.08 & 25.69 & 0.04 & 30.02 & 0.11 & 20.24 \\
\hline
\end{tabular}

Table 3 shows the water potential $(\mathrm{P})$ and humidity $\left(\mathrm{H}_{\mathrm{g}}\right)$ at 08:00, 13:00 and 17:00, during the 20 days of testing. As observed, at 08:00 the leaf water potential values of the purple elephant grass vary between $0.02 \mathrm{MPa}$ and $0.09 \mathrm{MPa}$ in humidity ranges of $6.24 \%$ and $28.08 \%$, and without irrigation vary between $0.02 \mathrm{MPa}$ and $0.21 \mathrm{MPa}$. In the irrigated area, moisture levels were higher; however, the water potential was lower. Ferrara et al. $\frac{13}{}$ also observed a reduction in 
water potential as soil moisture increases. At 13:00, in the pasture under irrigation the leaf water potential values vary between $0.03 \mathrm{MPa}$ and $0.10 \mathrm{MPa}$ and from $0.03 \mathrm{MPa}$ to $0.3 \mathrm{MPa}$ without irrigation showing temporary wilting in the pasture ${ }^{14}$, demonstrated that climatic conditions and time of day influence the magnitude of water potential. Finally, at 17:00 in the area with irrigation the water potential varies between $0.03 \mathrm{MPa}$ and $0.11 \mathrm{Mpa}$ and in the area without irrigation between $0.02 \mathrm{MPa}$ and $0.25 \mathrm{MPa}$.

Soil moisture decreased during the day (Table 3), except for the last days where there was higher humidity in the afternoon due to some precipitation which also affected the values in the crop without irrigation and decreased water potential values. Additionally, there is a variation between the values of water potential in the hours of the measurement with a tendency to increase at 13:00, probably caused by evapotranspiration occurred during the morning and high temperatures at this time of day. In the afternoon hours, decreases again but having values higher than those recorded in the morning.

The data in Table 3 were analyzed with variance analysis and Tukey's HSD (honest significant difference) test with the Statgraphics. The results are shown in Figure 1.

Figure 1-a shows that the values of water potential are more distributed below the average, whilst in humidity

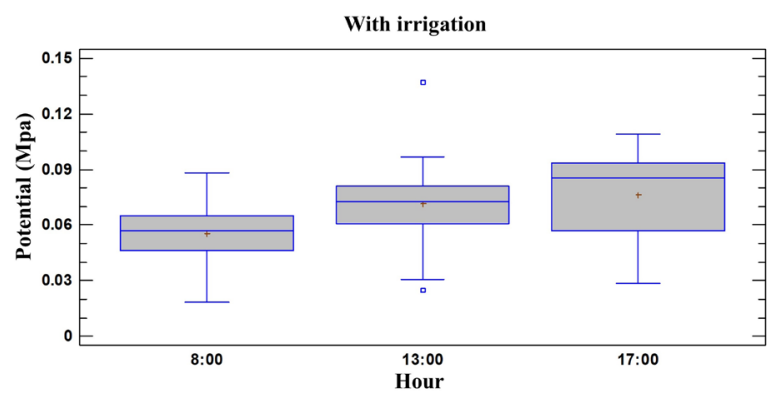

(a)

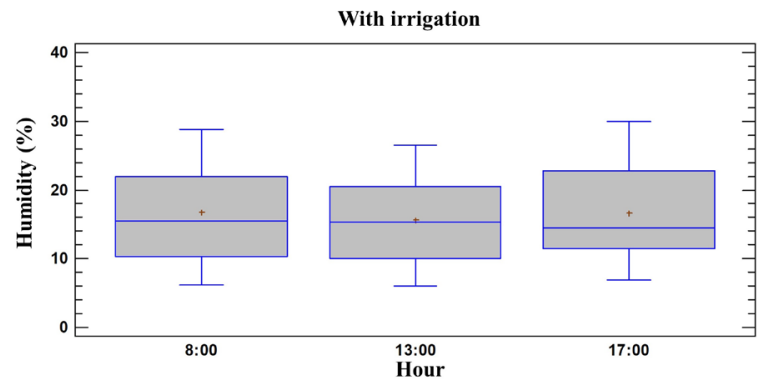

(c)
(Figure 1-c) the opposite happens, where is observed a concentration of the moisture values generate concentration in the water potential values. For the area without irrigation the water potential values at 8:00 and 13:00 are more dispersed below the mean, at 17:00 the opposite happens (Figure 1-b) and for moisture the values are more dispersed below the mean (Figure 1-d) indicating that high values of humidity produce low values of water potential. There is a statistically significant difference $(P<0.05)$ between the values of water potential at 08:00 and 13:00, this was also reported by Rojas-Jimenez and Gutiérre $z^{\frac{15}{5}}$. Figure 2 shows that the values of water potential increase as the soil moisture decreases, for both treatments. The determined equation can use to find the water potential in a soil with a sandy clay loam texture.

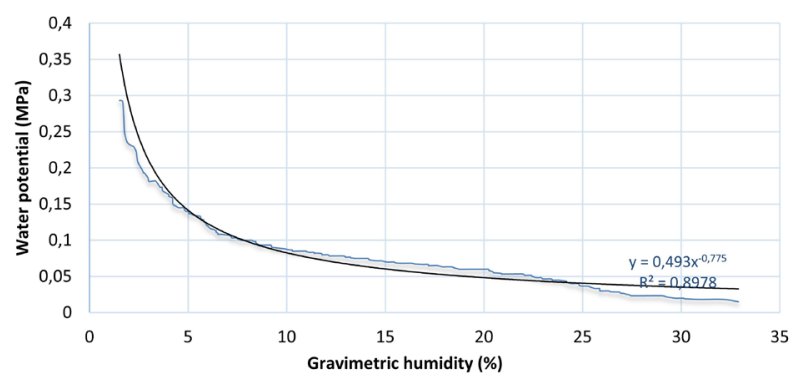

Figure 2. Characteristic curve of soil moisture and water potential.

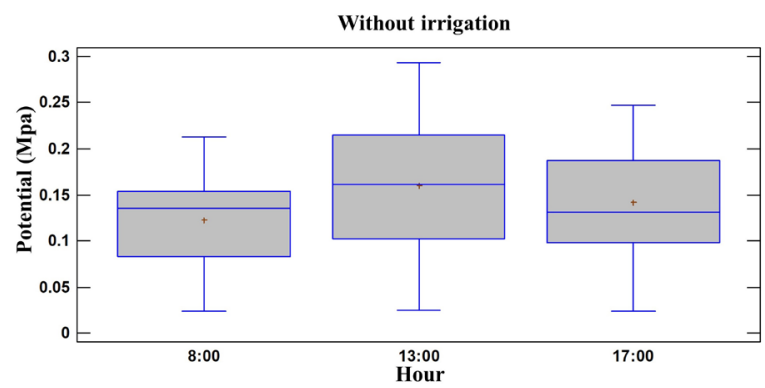

(b)

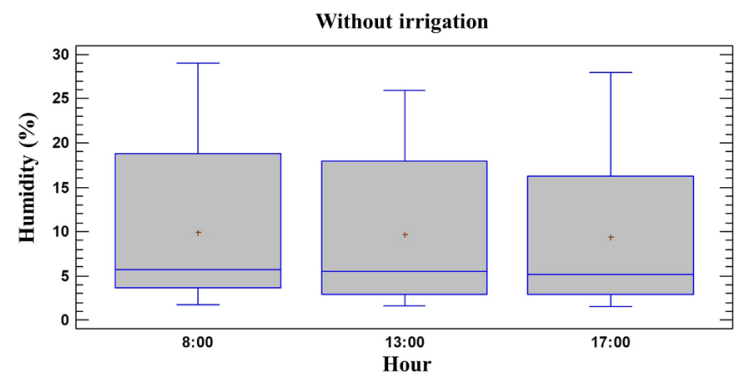

(d)

Figure 1. Water potential with respect to the hours of the day: (a) with irrigation, (b) without irrigation. Humidity with respect to the hours of the day: (c) with irrigation, (d) without irrigation. 
The purple elephant grass is classified as a C-4 plant; for having $\mathrm{CO}_{2}$ pumping intermediates, unforeseen stomatal closure can be allowed, and the continuity of the photosynthetic process is feasible, thanks to the $\mathrm{CO}_{2}$ reservoir. For this, it is more efficient in the use of water (transpiration) $)^{\frac{16}{6}}$.

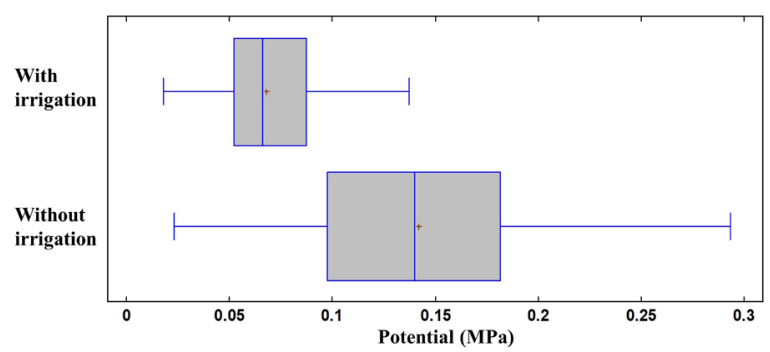

Figure 3. Distribution of water potential with and without irrigation.

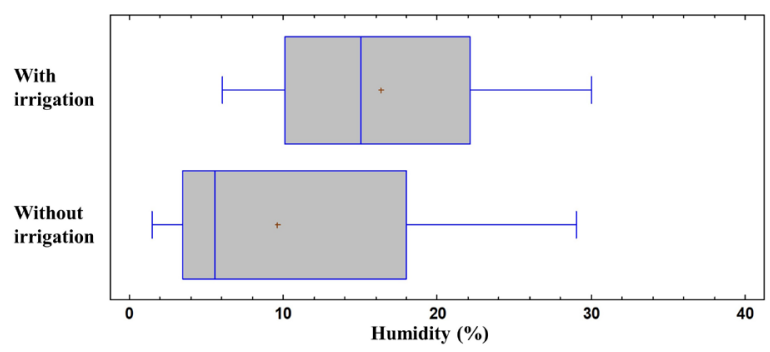

Figure 4. Distribution of humidity with and without irrigation.

Figure 3 shows that there is a concentration of data equal in terms of water potential for the two conditions of the crop. Regarding humidity (Figure 4), tends to concentrate in the first quartiles, caused by the precipitations that oscillated the humidity values in the last days.

Table 4 shows the crop yield. As can been seen, the irrigated grass had a higher production (yield) in Green Material (GM) and Dry Material (DM), the non-irrigated grass was subjected to an unfavorable hydric state which caused a lower growth of the leaves and the stem, this was also reported by Santos et al. ${ }^{17}$ and Marti-ón-Martínez et al. $\frac{18}{}$

Table 4. Crop yield

\begin{tabular}{|l|c|c|}
\hline Agricultural plot & $\begin{array}{l}\text { With } \\
\text { irrigation }\end{array}$ & $\begin{array}{l}\text { Without } \\
\text { irrigation }\end{array}$ \\
\hline Yield Average $\left(\mathrm{kg} / \mathrm{m}^{2}\right)(\mathrm{GM})$ & 7.27 & 4.125 \\
\hline Dry material \% $(\mathrm{DM})$ & 22.06 & 25.43 \\
\hline Yield DM $\left(\mathrm{kg} / \mathrm{m}^{2}\right)$ & 1.6 & 1.05 \\
\hline Yield DM $\left(\mathrm{kg} / \mathrm{m}^{2}\right)$ & 16 & 10.5 \\
\hline
\end{tabular}

\section{Conclusions}

The main conclusions of the study may be summarized as follows:

- There is an inverse relationship between humidity and the leaf water potential of purple elephant grass, with potential tendency. The determined equation can use to find the water potential in a soil with a sandy clay loam texture.

- With the passing of the day, the water potential increases as consequence of a reduction in soil moisture.

- The purple elephant grass tolerates drought, since under these conditions of humidity it remained in good condition, but when subjected to conditions without irrigation, its yield decreases significantly.

- The purple elephant grass maintains a great yield with humidity between $20 \%$ and $30 \%$ and potential between 0.03 and $0.05 \mathrm{MPa}$.

\section{Acknowledgement}

The authors are grateful to all officials of the laboratory of water and soil (LASA) of the University of Sucre for their collaboration, and to the owners of the farm "El Achiote" located in the town San Jorge de Sincelejo, department of Sucre, Colombia, for facilitating the crop and the irrigation system for the project.

\section{References}

1. Ruiz Corral JA, García GM, Díaz JLR, López HEF, Ojeda GR, Olmos JDM. Cambio climático y sus implicaciones en cinco zonas productoras de maíz en México. Revista Mexicana de Ciencias Agrícolas. 2015; 1(2):309-23.

2. Vélez JE, Álvarez-Herrera JG, Alvarado-Sanabria $\mathrm{OH}$. El Estrés Hídrico en Cítricos (Citrus spp.): Una revisión. Orinoquia. 2012; 16(2):32-9. Crossref.

3. Qui-ones A, Martínez-Alcántara B, Legaz F. Influence of irrigation system and fertilization management on seasonal distribution of $\mathrm{N}$ in the soil profile and on $\mathrm{N}$-uptake by citrus trees. Agriculture, Ecosystems and Environment. 2007; 122(3):399-409. Crossref.

4. Villagra PE, Giordano C, Alvarez JA, Cavagnaro JB, Guevara A, Carmen S, et al. Ser planta en el desierto: Estrategias de uso de agua y resistencia al estrés hídrico en el Monte Central de Argentina. Austral Ecology. 2011; 21(1):29-42. 
5. Quintal Ortiz WC, Pérez-Gutiérrez A, Moreno LL, May-Lara C, Sánchez ER, Martínez Chacón AJ. Uso de agua, potencial hídrico y rendimiento de chile habanero (Capsicum chinense Jacq.). Revista Fitotecnia Mexicana. 2012; 35(2):155-60.

6. Madera NB, Ortiz B, Bacab HM, Maga-a H. Influencia de la edad de corte del pasto morado (Pennisetum purpureum) en la producción y digestibilidad in vitro de la materia seca. Avances en Investigación Agropecuaria. 2013; 17(2):1-13.

7. Avalos JMM, Córdoba ET, Cid YB, Losada ED, Fernández IO. Relación entre humedad del suelo y estado hídrico de Albari-o bajo condiciones de riego y secano. Estudios en la Zona no Saturada del Suelo. 2013; 11:1-6.

8. López AG, González RC, José LMS. Efecto de la hora del día en el potencial hídrico foliar del sorgo y su relación con la humedad en el suelo. Revista Ciencias Técnicas Agropecuarias. 2010; 19(3):7-11.

9. Correa DLG, Vélez-Sánchez JE, Rodríguez JOO. Efecto del déficit hídrico en el crecimiento y desarrollo de frutos de naranja Valencia (Citrus sinensis Osbeck) en el piedemonte del Meta, Colombia. Acta Agronómica. 2013; 62(2):136-47.

10. May-Lara C, Pérez-Gutiérrez A, Ruiz-Sánchez E, Ic-Caamal AE, García-Ramírez A. Efecto de niveles de humedad en el crecimiento y potencial hídrico de Capsicum chinense Jacq. Y su relación con el desarrollo de Bemisia tabaci Genn. Trop Subtrop agroecosystems. 2011; 14(3):1039-45.
11. Instituto Geografico Agustin Codazzi (IGAC). Métodos analíticos del laboratorio de suelos. Igac; 2006. p. 1-648.

12. Keller J, Bliesner RD. Sprinkle and trickle irrigation. Van Nostrand Reinhold, New York; 1990. p. 1-30. Crossref.

13. Ferrara A, Lovelli S, Di Tommaso T, Perniola M. Flowering, growth and fruit setting in greenhouse bell pepper under water stress. Journal of Agronomy. 2011; 10(1):12-9. Crossref.

14. Ferreyra R, Selles G, Silva H, Ahumada R, Mu-oz I, Mu-oz V. Efecto del agua aplicada en las relaciones hídricas y productividad de la vid "Crimson Seedless. Pesqui Agropecuária Brasileira. 2006; 41(7):1109-18. Crossref.

15. Rojas-Jimenez K, Gutiérrez MV. Relaciones hídricas en árboles del bosque tropical seco: el caso de Enterolobium cyclocarpum. Revista Forestal mesoamericana Kurú. 2012; 8(20):1-8.

16. Taiz L, Zeiger E. Plant physiology. $3^{\text {rd }}$ Edition. Sinauer Associates Inc., Sunderland; 2002. p. 555-7.

17. Santos HRB, Pedrosa EMR, Nogueira RJMC, Rolim MM, Maranhão SRVL, Medeiros DB. Crescimento de três variedades de cana-de-açúcar submetidas a estresse hídrico associado à Meloidogyne incognita. Revista Brasileira de Ciências Agrárias. 2013; 8(4):547-54. Crossref.

18. Marti-ón-Martínez RJ, Vargas-Hernández JJ, López-Upton J, Gómez-Guerrero A, Vaquera-Huerta H. Respuesta de pinus pinceana gordon a estres por sequia y altas temperatura. Revista Fitotecnia Mexicana. 2010; 33(3):239-48. 